\title{
Retention, distribution, and excretion of lead by the rat after intravenous injection
}

\author{
A. MORgAN, A. HOLMES, AND J. C. EVANS \\ From the Environmental and Medical Sciences Division, Atomic Energy Research Establishment, Harwell, \\ Oxfordshire OX 11 ORA
}

ABSTRACT The distribution and excretion of lead was studied during a period of about a week after a single intravenous injection of ${ }^{203} \mathrm{~Pb}$ as chloride accompanied by less than $1 \mu \mathrm{g}$ of lead carrier. The peak concentration in venous blood was reached after about an hour when it contained 35 to $40 \%$ of the administered activity. The subsequent decline in concentration was much more rapid than is observed in man. The main storage organs were the kidneys and bone. Initially, $20 \%$ of the dose could be accounted for in the kidneys and the biological half-life was about 100 hours. The level in bone built up rapidly at first and then more slowly. After a week, between 25 and $30 \%$ of the dose was present in bone.

Petrol engine exhaust aerosols labelled with ${ }^{203} \mathrm{~Pb}$ have been administered to volunteers by Chamberlain et al. (1975) to study their deposition in the respiratory tract and the absorption of the associated lead. In complementary investigations, similar aerosols were administered to rats to study, in greater detail than is possible with volunteers, the distribution of absorbed lead at various times. To provide, for comparative purposes, information on the metabolism of lead introduced directly into the blood stream rats were injected intravenously with ${ }^{203} \mathrm{~Pb}$ in the form of chloride. The results of these investigations are described in this report and an account of the absorption and metabolism of lead administered to rats in exhaust particulates will be given elsewhere.

A number of workers have studied the retention and metabolism of lead in the rat after administration either by intravenous or intraperitoneal injection. Some have used ${ }^{203} \mathrm{~Pb}$ (Kello and Kostial, 1973; Kostial et al., 1973; Momčilović and Kostial, 1974) and others $210 \mathrm{~Pb}$ (Horiuchi and Horiuchi, 1958; Castellino and Aloj, 1964; Lucas and Stanford, 1967; Cohen, 1970; Torvik et al., 1974). In no case, however, has an attempt been made to follow the precise distribution of lead in all tissues during the few days immediately after administration.

\section{Materials and methods}

Male albino rats, about six months old, were used in

Received for publication 2 April 1976

Accepted for publication 27 September 1976 these experiments. Aliquots $(0.2 \mathrm{ml})$ of the active solution were injected into a tail vein of each rat under light ether anaesthesia. The $\gamma$-ray emissions of the syringes were counted before and after injection to obtain an estimate of the radioactive dose. After administration, the animals were maintained in individual cages on a cubed diet and water ad libitum. Faeces were collected daily and urine was absorbed on sheets of filter paper below the cages. Rats were killed by exsanguination under ether anaesthesia. Blood from the abdominal aorta was collected in tared containers with lithium heparin anticoagulant. The gastrointestinal tract, liver, kidneys, spleen, gonads, heart, and lungs were dissected out and in some cases the pelt was separated from the remaining carcass.

${ }^{203} \mathrm{~Pb}$ was obtained from the Medical Research Council Cyclotron Unit, Hammersmith Hospital. This nuclide has a half-life of $\mathbf{5 2}$ hours and emits a $279 \mathrm{KeV} \gamma$-ray in $99 \%$ of its disintegrations. The level of lead carrier in the source supplied was about $1 \mu \mathrm{g}$. Aliquots of the solution were diluted with various amounts of pyrogen-free saline in glass ampoules and sterilised in an autoclave. There was some loss of radioactivity on the walls of the ampoules and one was selected for use in which the specific activity was about $2-5 \mu \mathrm{Ci} \mathrm{ml}^{-1}$.

The ${ }^{203} \mathrm{~Pb}$ contents of the various samples of tissue and excreta were measured by counting between coaxial NaI(T1) detectors $(15 \mathrm{~cm} \times 9 \mathrm{~cm})$ and comparing the activity, after correction for radioactive decay, with that of appropriate liquid standards. For each animal the dose was taken as the total ${ }^{203} \mathrm{~Pb}$ 
Table 1 Distribution of ${ }^{203} \mathrm{~Pb}$ in the tissue and excreta of rats killed at various times after a single intravenous injection of ${ }^{203} \mathrm{~Pb}$ as chloride (per cent of dose)

\begin{tabular}{|c|c|c|c|c|c|c|c|c|c|c|c|}
\hline $\begin{array}{l}\text { Rat } \\
\text { Sample }\end{array}$ & $\begin{array}{l}1.1 \\
(1 h)\end{array}$ & $\begin{array}{l}1.2 \\
(5 h)\end{array}$ & $\begin{array}{l}1.3 \\
(24 h)\end{array}$ & $\begin{array}{l}1.4 \\
(48 h)\end{array}$ & $\begin{array}{l}1.5 \\
(123 h)\end{array}$ & $\begin{array}{l}2.1 \\
(19 h)\end{array}$ & $\begin{array}{l}2.2 \\
(19 h)\end{array}$ & $\begin{array}{l}2.3 \\
(19 h)\end{array}$ & $\begin{array}{l}3.1 \\
(17 \mathrm{~min})\end{array}$ & $\begin{array}{l}3.2 \\
(30 \mathrm{~min})\end{array}$ & $\begin{array}{l}3.3 \\
(1 h)\end{array}$ \\
\hline Blood & $15 \cdot 1$ & $13 \cdot 2$ & $5 \cdot 4$ & $2 \cdot 1$ & 0.7 & $7 \cdot 5$ & $7 \cdot 9$ & $6 \cdot 7$ & $8 \cdot 2$ & $10 \cdot 7$ & $11 \cdot 8$ \\
\hline Kidneys & 16.8 & $16 \cdot 5$ & $15 \cdot 0$ & 16.0 & $7 \cdot 7$ & $18 \cdot 8$ & 21.9 & $21 \cdot 6$ & $22 \cdot 8$ & $19 \cdot 1$ & 19.9 \\
\hline Liver & $18 \cdot 8$ & $15 \cdot 5$ & 10.0 & 4.0 & 1.4 & $17 \cdot 4$ & $7 \cdot 2$ & $11 \cdot 1$ & 23.0 & 26.5 & 25.4 \\
\hline Spleen & 0.3 & 0.3 & 0.2 & 0.2 & - & 1.0 & 0.4 & 0.4 & 0.8 & $1 \cdot 2$ & 1.0 \\
\hline GI tract & 6.8 & 9.9 & $6 \cdot 7$ & $4 \cdot 0$ & 0.9 & $5 \cdot 9$ & 6.5 & $8 \cdot 5$ & $5 \cdot 1$ & 6.0 & $6 \cdot 2$ \\
\hline Lungs & 1.4 & $1 \cdot 3$ & 0.6 & 0.3 & $0 \cdot 2$ & 1.0 & 0.7 & 0.6 & 1.8 & 1.7 & 1.7 \\
\hline Gonads & 0.6 & 0.4 & 0.2 & $0 \cdot 1$ & $0 \cdot 1$ & ND & ND & ND & ND & ND & ND \\
\hline Carcass & $39 \cdot 2$ & $40 \cdot 7$ & $45 \cdot 8$ & $33 \cdot 1$ & $33 \cdot 7$ & $34 \cdot 4$ & $38 \cdot 6$ & $35 \cdot 5$ & 38.4 & $34 \cdot 8$ & $34 \cdot 1$ \\
\hline Systemic & 98.9 & $97 \cdot 9$ & 83.9 & 59.8 & $44 \cdot 7$ & 86.0 & $83 \cdot 2$ & 84.4 & $100 \cdot 0$ & $100 \cdot 0$ & $100 \cdot 0$ \\
\hline Urine & $1 \cdot 1$ & $2 \cdot 1$ & $7 \cdot 7$ & $19 \cdot 1$ & $24 \cdot 5$ & $5 \cdot 2$ & $7 \cdot 7$ & 9.0 & - & - & - \\
\hline Faeces & - & - & $8 \cdot 3$ & $21 \cdot 0$ & $30 \cdot 8$ & $8 \cdot 8$ & $9 \cdot 1$ & 6.6 & - & - & - \\
\hline Total & 100 & 100 & 100 & 100 & 100 & 100 & 100 & 100 & 100 & 100 & 100 \\
\hline
\end{tabular}

$\mathrm{ND}=$ not determined.

accounted for in the various samples of tissue and excreta. The radioactivity associated with the tail was subtracted from the total to eliminate any ${ }^{203} \mathrm{~Pb}$ remaining at the site of injection although this was, in most cases, only a few per cent of the total. In general there was excellent agreement between the estimates of administered ${ }^{203} \mathrm{~Pb}$ obtained (a) by counting the syringes before and after injection and (b) from the radioactivity in the various tissues and excreta.

Results

DETAILS OF THE VARIOUS EXPERIMENTS

In the first experiment five rats with a mean weight of $354 \pm 38 \mathrm{~g}$ were used. The average dose, corrected to the time of administration was $0.44 \mu \mathrm{Ci}$. Animals were killed serially at $1,5,24,48$, and 123 hours after administration.

The second experiment was performed to investigate methods of separating bone from soft tissue. Three rats were used with a mean weight of $413 \pm 6 \mathrm{~g}$ and the average dose was $0.71 \mu \mathrm{Ci}$. All three animals were killed after 19 hours and dissected in the usual manner. The carcass of the first rat (2.1) after removal of a single femur was digested three times with boiling $N$ sodium hydroxide solution. The carcass of the second rat (2.2) after removal of a femur, was treated by heating in a pressure cooker for 1 hour. Both femurs were removed from the carcass of the third animal.

The purpose of the third experiment was to obtain more information on the uptake of ${ }^{203} \mathrm{~Pb}$ in bone, particularly during the first day after administration. Seven rats were used with a mean weight of $488 \pm 36$ g. The average dose, corrected to the time of administration, was $0.39 \mu \mathrm{Ci}$. Single animals were killed after 17 minutes, 30 minutes, 59 minutes, and 25 hours; three were killed after seven days. In each
Table 2 Volume of blood sampled and percent of dose in blood sampled and in total blood

\begin{tabular}{|c|c|c|c|c|c|}
\hline \multirow[t]{2}{*}{ Rat no. } & \multirow[t]{2}{*}{ Weight $(g)$} & \multicolumn{2}{|c|}{ Blood sampled } & \multicolumn{2}{|c|}{ Total blood } \\
\hline & & $\begin{array}{l}\text { Vol. } \\
(\mathrm{ml})\end{array}$ & $\begin{array}{l}{ }^{203} \mathrm{~Pb} \\
(\% \text { dose })\end{array}$ & $\begin{array}{l}\text { Vol. } \\
(m l)\end{array}$ & $\begin{array}{l}{ }^{203} \mathrm{~Pb} \\
(\% \text { dose) }\end{array}$ \\
\hline $\begin{array}{l}1.1 \\
1.2 \\
1.3 \\
1.4 \\
1.5\end{array}$ & $\begin{array}{l}333 \\
310 \\
351 \\
410 \\
367\end{array}$ & $\begin{array}{l}7 \cdot 1 \\
7 \cdot 9 \\
6 \cdot 8 \\
6 \cdot 8 \\
7 \cdot 3\end{array}$ & $\begin{array}{r}15 \cdot 1 \\
13 \cdot 2 \\
5 \cdot 4 \\
2 \cdot 1 \\
0 \cdot 7\end{array}$ & $\begin{array}{l}20.0 \\
18.6 \\
21 \cdot 1 \\
24.6 \\
22.0\end{array}$ & $\begin{array}{r}42 \cdot 5 \\
31 \cdot 1 \\
16.8 \\
7 \cdot 6 \\
2 \cdot 1\end{array}$ \\
\hline $\begin{array}{l}2.1 \\
2.2 \\
2.3\end{array}$ & $\begin{array}{l}406 \\
416 \\
417\end{array}$ & $\begin{array}{l}11 \cdot 8 \\
11 \cdot 5 \\
11 \cdot 1\end{array}$ & $\begin{array}{l}7 \cdot 5 \\
7 \cdot 9 \\
6 \cdot 7\end{array}$ & $\begin{array}{l}24 \cdot 4 \\
25 \cdot 0 \\
25 \cdot 0\end{array}$ & $\begin{array}{l}15 \cdot 5 \\
17 \cdot 2 \\
15 \cdot 1\end{array}$ \\
\hline $\begin{array}{l}3.1 \\
3.2 \\
3.3\end{array}$ & $\begin{array}{l}433 \\
483 \\
465\end{array}$ & $\begin{array}{r}9.9 \\
10.4 \\
9.3\end{array}$ & $\begin{array}{r}8 \cdot 2 \\
10 \cdot 7 \\
11 \cdot 8\end{array}$ & $\begin{array}{l}26.0 \\
29.0 \\
27.9\end{array}$ & $\begin{array}{l}21 \cdot 5 \\
29 \cdot 8 \\
35 \cdot 4\end{array}$ \\
\hline
\end{tabular}

case, both femurs were removed from the carcass and their combined ${ }^{203} \mathrm{~Pb}$ content was measured separately.

DISTRIBUTION OF ${ }^{203} \mathrm{~Pb}$

The distribution of ${ }^{203} \mathrm{~Pb}$ together with the amounts excreted up to the time of death are given in Table 1 in which the activity of each sample is expressed as a percentage of the dose.

The levels of ${ }^{203} \mathrm{~Pb}$ in blood are summarised in Table 2. Also shown in Table 2 are estimates of the total blood volumes based on the information given by D'Amour et al. (1953) that a $300 \mathrm{~g}$ rat contains 18 $\mathrm{ml}$ of blood. If these estimates are correct then, on average, $37 \%$ of the total blood volume was collected. The last column of Table 2 gives estimates of the dose present in the total blood of each animal. The percentages of the dose in blood at various times after administration are shown in Fig. 1a which indicates that the maximum concentration was reached about 1 hour after injection after which 


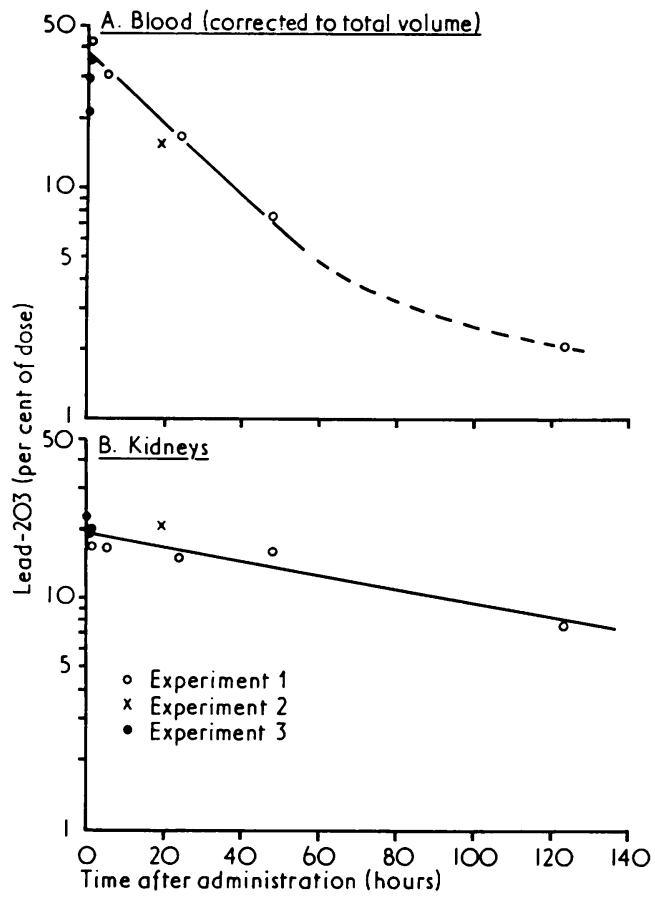

Fig. 1 Level of ${ }^{203} \mathrm{~Pb}$ in blood (a) and in kidneys (b) at various times after administration.

there was a relatively rapid decline. Initially, the decrease in concentration can be represented by an exponential expression with a half-time of 20 hours, but it seems likely that a longer-lived component must be invoked to describe the decline at later times. In the first experiment, blood samples were centrifuged immediately after collection and the erythrocytes were washed with isotonic saline. The ${ }^{203} \mathrm{~Pb}$ content of the plasma did not exceed $2 \%$ of that in whole blood and, as there was generally some evidence of haemolysis, it can be assumed that at least $98 \%$ of the lead in blood was associated with the red cells.

As shown in Fig. 1b the maximum level of ${ }^{203} \mathrm{~Pb}$ in the kidneys was reached rapidly. The results of the third experiment indicate that the maximum uptake was reached within 15 minutes of injection. At this time the fraction of the dose in the kidneys was slightly less than in the liver but, because the kidneys are lighter, the actual lead concentration was greater. A maximum of about $20 \%$ of the administered ${ }^{203} \mathrm{~Pb}$ appeared in the kidneys and the subsequent decline can be expressed in terms of a single exponential expression with a half-time of about 100 hours which is longer than the corresponding value for blood. The comparatively high level of lead in the kidneys was also reported by Momčilović and Kostial
(1974) after intraperitoneal injection of ${ }^{203} \mathrm{~Pb}$ in the adult rat, although in the suckling, uptake was greater in the liver than in the kidneys. The presence of lead in intranuclear inclusion bodies, obtained from rat kidneys, has been described (Goyer et al., 1970; Choie and Richter, 1972),

As in the kidneys, the maximum level of ${ }^{203} \mathrm{~Pb}$ in the liver was reached rapidly, certainly within the first hour after administration. At this time, the liver contained slightly more of the injected dose than the kidneys although in terms of concentration the level was much lower. Initially ${ }^{203} \mathrm{~Pb}$ was rapidly removed from the liver (see Fig. 2a) with a half-time of about

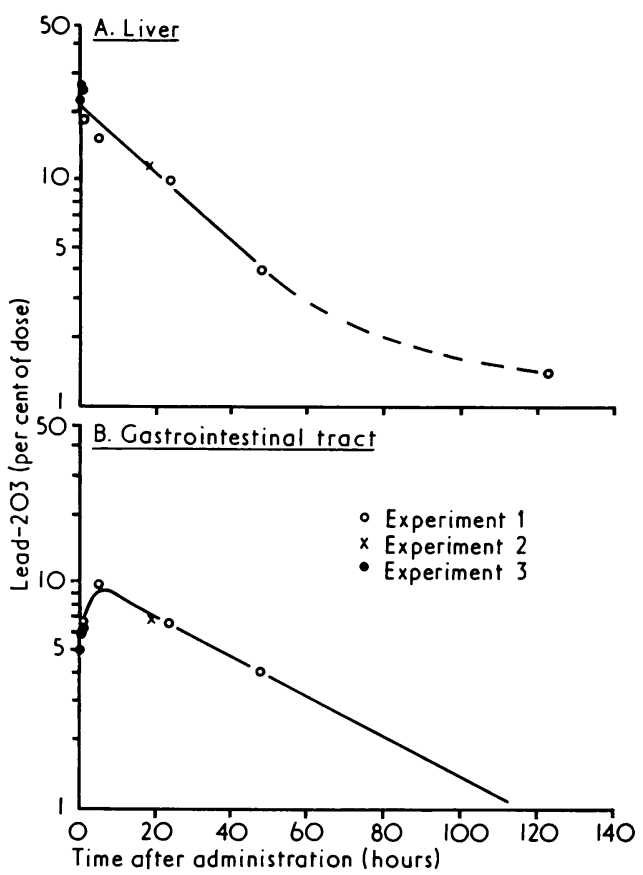

Fig. 2 Level of ${ }^{203} \mathrm{~Pb}$ in the liver (a) and in the gastrointestinal tract (b) at various times after adininistration.

20 hours, but there is some evidence that a slower clearance phase is required to describe the behaviour at later times. The similarity between the rate of removal of ${ }^{203} \mathrm{~Pb}$ from the blood stream and from the liver is very marked and indeed the liver must account for a large fraction of the blood which is not recovered from the abdominal aorta at death.

As shown in Fig. $2 \mathrm{~b}$ the maximum level of ${ }^{203} \mathrm{~Pb}$ in the gastrointestinal tract was not reached until about five hours after injection after which it declined with an apparent half-time of about 40 hours. Comparing the maximum level (about $10 \%$ of the dose) with that excreted in faeces during the 24 


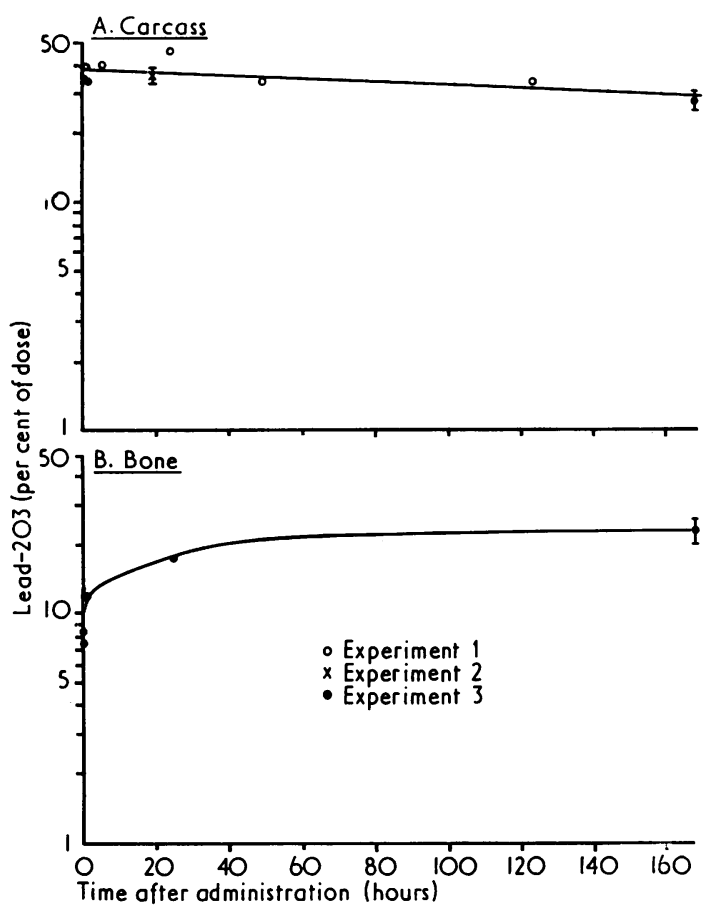

Fig. 3 Level of ${ }^{203} \mathrm{~Pb}$ in the carcass (a) and in bone (b) at various times after administration.

hours after administration leads one to conclude that the ${ }^{203} \mathrm{~Pb}$ is associated with the contents of the lumen of the gastrointestinal tract rather than with the tract itself.

As shown in Fig. 3a, the ${ }^{203} \mathrm{~Pb}$ content of the carcass (which includes bone, soft tissue, and skin together with some of the blood) decreased from an initial level of 35 to $40 \%$ of the dose to a little less than $30 \%$ after seven days. In the first experiment, the skin was separated from the carcass and its activity measured separately. After one hour, $6 \%$ of the dose was associated with the pelt but this decreased to $1.5 \%$ after 123 hours. The very slow decline in the ${ }^{203} \mathrm{~Pb}$ content of the carcass indicates either that the uptake in bone is very rapid and does not change much thereafter, or that there is a significant level of ${ }^{203} \mathrm{~Pb}$ in soft tissue initially, and that its decline is matched by a corresponding uptake in bone.

EXCRETION OF $203 \mathrm{~Pb}$

The faecal, urinary, and total excretion of ${ }^{203} \mathrm{~Pb}$ by rats during various periods after examination are shown in Table 3. During the first day similar amounts were excreted in urine and faeces (average faeces/urine ratio 0.9 ) but some of the ${ }^{203} \mathrm{~Pb}$ which
Table 3 Excretion of ${ }^{203} \mathrm{~Pb}$ in urine and faeces $(\%$ of dose)

\begin{tabular}{|c|c|c|c|c|c|}
\hline $\begin{array}{l}\text { Rat } \\
\text { no. }\end{array}$ & $\begin{array}{l}\text { Sampling } \\
\text { period } \\
\text { (h) }\end{array}$ & $\begin{array}{l}\text { Urine } \\
(\%)\end{array}$ & $\begin{array}{l}\text { Faeces } \\
(\%)\end{array}$ & $\begin{array}{l}\text { Total } \\
(\%)\end{array}$ & $F / U$ \\
\hline \multirow[t]{2}{*}{$\begin{array}{l}2.1 \\
2.2 \\
2.3\end{array}$} & $\begin{array}{l}0-19 \\
0-19 \\
0-19\end{array}$ & $\begin{array}{l}5.2 \\
7 \cdot 7 \\
9 \cdot 0\end{array}$ & $\begin{array}{l}8 \cdot 8 \\
9 \cdot 1 \\
6 \cdot 6\end{array}$ & $\begin{array}{l}14.0 \\
16.8 \\
15.6\end{array}$ & \\
\hline & Mean & $7 \cdot 3$ & $8 \cdot 2$ & $15 \cdot 5$ & $1 \cdot 1$ \\
\hline $\begin{array}{l}1.3 \\
1.4 \\
1.5 \\
3.4 \\
3.5 \\
3.6 \\
3.7\end{array}$ & $\begin{array}{l}0-24 \\
0-24 \\
0-24 \\
0-24 \\
0-24 \\
0-24 \\
0-24\end{array}$ & $\begin{array}{r}7 \cdot 7 \\
14 \cdot 6 \\
14 \cdot 8 \\
10 \cdot 2 \\
9 \cdot 2 \\
9 \cdot 2 \\
11 \cdot 0\end{array}$ & $\begin{array}{r}8 \cdot 3 \\
11 \cdot 4 \\
14 \cdot 6 \\
8 \cdot 6 \\
8 \cdot 5 \\
10 \cdot 1 \\
10 \cdot 3\end{array}$ & $\begin{array}{l}16 \cdot 0 \\
26 \cdot 0 \\
29 \cdot 4 \\
18 \cdot 8 \\
17 \cdot 7 \\
19 \cdot 3 \\
21 \cdot 3\end{array}$ & \\
\hline 3.7 & Mean & $11 \cdot 0$ & $10 \cdot 3$ & $21 \cdot 2$ & 0.9 \\
\hline \multirow[t]{2}{*}{$\begin{array}{l}1.4 \\
1.5\end{array}$} & $\begin{array}{l}24-48 \\
24-48\end{array}$ & $\begin{array}{l}4 \cdot 5 \\
4 \cdot 0\end{array}$ & $\begin{array}{l}9 \cdot 6 \\
8.5\end{array}$ & $\begin{array}{l}14 \cdot 1 \\
12 \cdot 5\end{array}$ & \\
\hline & Mean & $4 \cdot 3$ & $9 \cdot 1$ & 13.5 & 2.1 \\
\hline $\begin{array}{l}1.5 \\
1.5\end{array}$ & $\begin{array}{l}48-96 \\
96-123\end{array}$ & $\begin{array}{l}2.0 \\
1.7\end{array}$ & $\begin{array}{l}3.0 \\
1.7\end{array}$ & $\begin{array}{l}5.0 \\
3.4\end{array}$ & $\begin{array}{l}1.5 \\
1\end{array}$ \\
\hline
\end{tabular}

will eventually appear in faeces was still contained in the gut at this time. The clearance of residual ${ }^{203} \mathrm{~Pb}$ in faeces at later times probably accounts for the enhanced faeces/urine ratio during the subsequent two to three days. A similar effect was noted by Lucas and Stanford (1967) who investigated the excretion of lead by rats after its intravenous injection as $210 \mathrm{~Pb}$. After this initial period, they found an average ratio of a little more than unity during a period of several weeks. For the first group of animals, values for renal clearance were determined for each urine sampling period, taking the ${ }^{203} \mathrm{~Pb}$ concentration in blood at the mid-time of the sampling period. The average value obtained was $0.45 \pm 0.13 \mathrm{ml} \mathrm{h}^{-1}$.

\section{Discussion}

It is clear from the work of Momčilović and Kostial (1974) that the retention by the rat of intravenously administered lead depends critically upon the age of the animal and is much higher in suckling than in adult rats. Values obtained by these workers for the retention of ${ }^{203} \mathrm{~Pb}$ by adult (120-day-old) female rats after intraperitoneal injection are given in Fig. 4. The values can be resolved by a two-component exponential expression with half-times corresponding to 21 and 280 hours. Values for retention deduced from the results of the current experiments, by subtracting the total amount of ${ }^{203} \mathrm{~Pb}$ excreted from the dose, are shown in Fig. 4 and are somewhat greater than those of Momčilović and Kostial (1974). The curve describing retention cannot be extrapolated back to $100 \%$ 


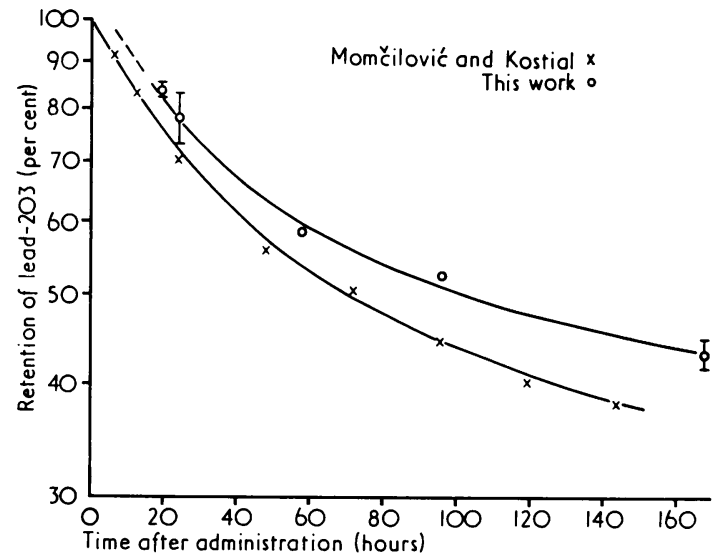

Fig. 4 Retention of ${ }^{203} \mathrm{~Pb}$ estimated by subtracting the excreted activity from the dose.

at zero time because of the time lag between the secretion of ${ }^{203} \mathrm{~Pb}$ into the gastrointestinal tract and its excretion some hours later in faeces. Cohen (1970) measured the retention of $210 \mathrm{~Pb}$ by rats after intravenous injection using an in vivo scintillation technique. His results are consistent with a retention of $50 \%$ after about a week which is in line with our own values. The only anomalous data on retention are those of Castellino and Aloj (1964) whose values are considerably greater than those reported elsewhere, particularly at later times. It should be pointed out however that they administered ${ }^{210} \mathrm{~Pb}$ accompanied by $100 \mu \mathrm{g}$ of lead carrier, a greater quantity than used by other workers.

As pointed out above, the ${ }^{203} \mathrm{~Pb}$ content of the carcass declines very slowly and it is not clear what are the relative contributions from ${ }^{203} \mathrm{~Pb}$ in soft tissue and in bone. In an attempt to measure ${ }^{203} \mathrm{~Pb}$ in bone directly, the carcass of rat 2.1 was digested three times with boiling $N$ sodium hydroxide solution and that of rat 2.2 in a pressure cooker for one hour. The bones were separated from the treated carcasses and $\gamma$-counted to determine the ${ }^{203} \mathrm{~Pb}$ content. In addition, the ${ }^{203} \mathrm{~Pb}$ content of femurs dissected out before treatment, was compared with that of treated femurs to assess the extent to which ${ }^{203} \mathrm{~Pb}$ had been removed by the respective treatments. Both femurs were dissected from the carcass of rat 2.3. The results of these measurements are given in Table 4 from which it is apparent that treatment with boiling caustic soda removes more than half the ${ }^{203} \mathrm{~Pb}$ from the femur. Even the comparatively mild treatment in a pressure cooker removed a significant amount of activity. The specific activities of the various bones, isolated from the carcass of rat 2.2, were measured and are listed
Table $4 \quad{ }^{203} \mathrm{~Pb}$ in treated and untreated femurs $(\%$ of dose)

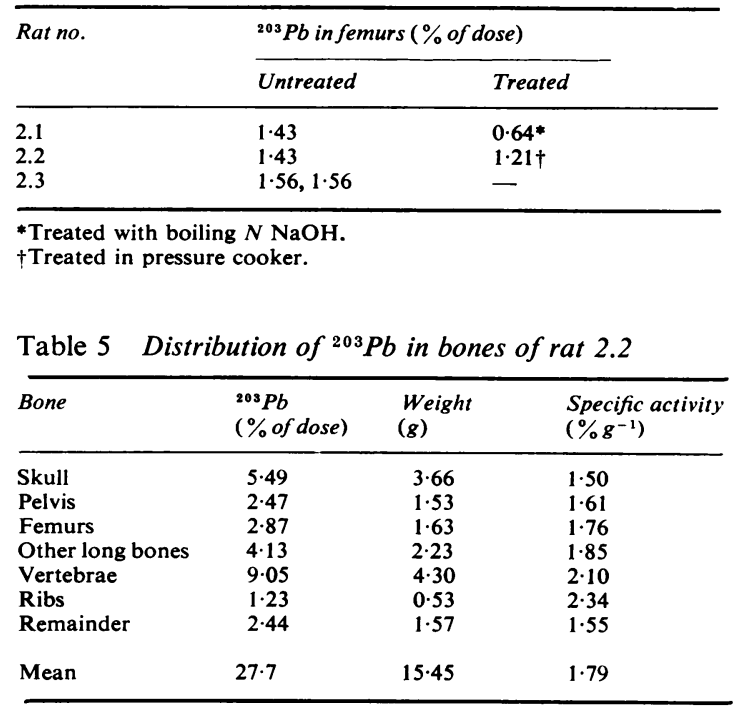

in Table 5. The ribs and vertebrae had the highest specific activity and the skull the lowest.

It can be seen from Table 5 that for rat 2.2 the femurs accounted for $10.5 \%$ of the total bone weight and also that the specific activity of the femur is close to the average value for the whole skeleton. This information was used to derive the ${ }^{203} \mathrm{~Pb}$ activity in the skeletons of the rats in the third experiment in which the ${ }^{203} \mathrm{~Pb}$ levels in the femurs were measured. The results are shown in Fig. $3 \mathrm{~b}$ and it can be seen that, after one hour, bone accounts for about one-third of the ${ }^{203} \mathrm{~Pb}$ content of the carcass and about one-half after 24 hours. After seven days ${ }^{203} \mathrm{~Pb}$ in bone accounts for most of the activity associated with the carcass. It appears therefore that the relative constancy of the ${ }^{203} \mathrm{~Pb}$ content of the carcass is accounted for by the loss of activity from soft tissue being very largely compensated by the uptake in bone. It seems that ultimately, between 25 and $30 \%$ of the dose will appear in bone. This agrees with the results of Cohen (1970) who found between 25 and $30 \%$ of $210 \mathrm{~Pb}$ in the skeleton of rats at one, three, and six days after its intravenous injection. The same author reports that, after 11 months, $12.5 \%$ of the dose was still present in the skeleton which implies that the biological half-life is of the order of a year. After intravenous injection of $210 \mathrm{~Pb}$ in the beagle, Lloyd et al. (1975) found $24 \%$ of the dose in the skeleton 28 days later indicating that the fraction of the dose going to bone may be similar to that in the rat. A greater skeletal uptake is reported by Strehlow (1971) for the baboon in which $40 \%$ of 
the dose of ${ }^{210} \mathrm{~Pb}$ was present in bone 28 days after injection.

It is clear that the main difference between the metabolism of lead in the rat and in man is in the rate of turnover in blood. In the rat, the peak concentration in venous blood is reached about one hour after injection when 35 to $40 \%$ of the administered ${ }^{203} \mathrm{~Pb}$ can be accounted for in blood. The level in blood declines fairly rapidly thereafter and after two days only about $5 \%$ of the dose remains in blood. The behaviour of lead injected intravenously into human subjects is quite different (Booker et al., 1969); the maximum concentration is not reached until about 24 hours after injection and then declines relatively slowly with a half-time of 15 days. It would be interesting to know if this is due to a difference in binding of lead in the erythrocytes of the two species or to a difference in the life-span of the erythrocytes.

This work was carried out under contract number 024-74-1 ENV-UK of the EEC Environmental Research Programme. The authors gratefully acknowledge the assistance of $\mathrm{Mr} \mathrm{A}$. E. Lally and $\mathrm{Mr} \mathrm{D}$. A. Brown who treated the carcasses to extract the bones.

\section{References}

Booker, D. V., Chamberlain, A. C., Newton, D., and Stott, A. N. B. (1969). Uptake of radioactive lead following inhalation and injection. British Journal of Radiology, 42, 457-466.

Castellino, N., and Aloj, S. (1964). Kinetics of the distribution and excretion of lead in the rat. British Journal of Industrial Medicine, 21, 308-314.

Chamberlain, A. C., Clough, W. S., Heard, M. J., Newton, D., Stott, A. N. B., and Wells, A. C. (1975). Uptake of lead by inhalation of motor exhaust. Proceedings of the Royal Society, Series B, 192, 77-110.

Choie, D. D., and Richter, G. W. (1972). Lead poisoning: rapid formation of intranuclear inclusions. Science, 177, 1194-1195.

Cohen, N. (1970). The retention and distribution of lead-210 in the adult baboon. PhD thesis, New York University.

D'Amour, F. E., Blood, F. R., and Belden, D. A. (1953). Manual for Laboratory Work in Mammalian Physiology. University Press: Chicago.

Goyer, R. A., May, P., Cates, M. M., and Krigman, M. R. (1970). Lead and protein content of isolated intranuclear inclusion bodies from kidneys of lead-poisoned rats. Laboratory Investigation, 22, 245-251.

Horiuchi, I., and Horiuchi, S. (1958). The fate of lead in the body-experiment with $\mathrm{RaD}$. Proceedings of 2 nd Japanese Conference on Radioisotopes. AEC-tr 4482. United States Atomic Energy Commission, Division of Technical Information.

Kello, D., and Kostial, K. (1973). The effect of milk diet on lead metabolism in rats. Environmental Research, 6, 355360.

Kostial, K., Kello, D., and Harrison, G. H. (1973). Comparative metabolism of lead and calcium in young and adult rats. Internationales Archiv für Arbeitsmedizin, 31, 159-161.

Lloyd, R. D., Mays, C. W., Atherton, D. R., and Bruenger, F. W. (1975). ${ }^{210} \mathrm{~Pb}$ studies in beagles. Health Physics, 28, 575-583.

Lucas, H. F., and Stanford, J. E. (1967). Excretion and retention of lead-210 in rats. Radiological Physics Division Annual Report, Argonne National Laboratory ANL 7360, pp. 105-110.

Momčilović, B., and Kostial, K. (1974). Kinetics of lead retention and distribution in suckling and adult rats. Environmental Research, 8, 214-220.

Strehlow, C. D. (1971). The use of deciduous teeth as indicators of lead exposure. PhD thesis, New York University.

Torvik, E., Pfitzer, E., Kereiakes, J. G., and Blanchard, R. (1974). Long term effective half-lives for lead-210 and polonium-210 in selected organs of the male rat. Health Physics, 26, 81-87. 